\title{
Evaluasi Kinerja Perbankan ASEAN Terkait Peningkatan Risiko Sistemik dalam Integrasi Pasar Perdagangan Bebas Masyarakat Ekonomi ASEAN (MEA)
}

\author{
Rinda Siaga $\mathbf{P}^{*}$ \\ Universitas Islam 45 \\ Jl Cut Meutia No.83 Bekasi, Jawa Barat \\ *correspondence email: rindasiaga@ymail.com
}

\begin{abstract}
This study is aimed to provide an evaluation of banking performance in ASEAN given the inclusion of the ASEAN Economic Community (AEC) which is associated with an increase in potential systemic risk. Some of the main findings in this study are: (a) the increase in systemic risk is influenced by the increase in risk on asset quality as seen from the increase in the percentage of non-performing loans; (b) bank liquidity has a significant positive effect on increasing systemic risk; (c) banks with large capital can exert influence over increased systemic risk (in a $90 \%$ confidence level but here we use $95 \%$ confidence level). The government is expected to be able to mitigate the increase in potential systemic risks, especially after the integration of free trade in ASEAN.
\end{abstract}

Keywords: Asset quality; Liquidity; Capital; Systemic Risk; Bank

\section{PENDAHULUAN}

Masyarakat Ekonomi ASEAN (MEA) merupakan sebuah bentuk integrasi kerjasama perdagangan bebas antar negara-negara di kawasan Asia Tenggara. Berdasarkan dokumen MoU antara the Mekong River Commision Secretariat dan the ASEAN Secretariat (2010), Blueprint integrasi MEA sudah ada sejak event ASEAN Summits 2007-2008 dan roadmap kerjasama telah disusun untuk tahun 2009 hingga 2015. Negara-negara ASEAN telah mempersiapkan strategi dan program kerja terkait dengan persiapan MEA yang mulai diterapkan pada tahun 2015, termasuk pemerintah Republik Indonesia yang mengeluarkan Keppres No.37 tahun 2014 Tentang komite Nasional Persiapan Pelaksanaan MEA dan Inpres No. 6 Tahun 2014 Tentang Peningkatan daya Saing Nasional Dalam Rangka Menghadapi MEA.

Indonesia adalah salah satu dari negara-negara berkembang di kawasan ASEAN yang masuk dalam nota kesepakatan MEA yang meski telah melakukan program persiapan menghadapi tantangan global perdagangan bebas di kawasan ASEAN, Indonesia tidak lepas dari dampak krisis global pada tahun 2007-2008. Terbukti, tingkat Gross Domestic Product (GDP) Indonesia pada 2007-2008 tidak mengalami peningkatan dan harga saham rata-rata mengalami penurunan meski tidak setajam negara-negara di kawasan ASEAN lainnya (Datastream ThompsonReuters, 2019). Krisis 2007-2008 mempengaruhi stabilitas keuangan akibat tingginya angka kredit macet mengingat adanya fluktuasi siklus bisnis dari negara-negara maju yang menyebabkan peningkatan risiko default di negara-negara berkembang. Pangestuti (2018) menyebutkan bahwa pada saat krisis global 2007-2008, pertumbuhan perekonomian Malaysia mengalami penurunan hingga jatuh pada posisi -3, juga tingkat Non Performing Loan (NPL) perbankan di Thailand rata-rata di atas 5\% hingga menyentuh angka 12\% dan menyebabkan default pada dua bank besar di Thailand. Bank menjadi sumber keuangan utama pada sektor bisnis swasta di negara-negara Asia, sehingga stabilitas perbankan di wilayah ini menjadi isu yang penting (Adams, 2008)

Pada tahun 2017, ASEAN Community Progress Monitoring System (ACPMS) yang ditunjuk untuk melakukan evaluasi terhadap hasil penerapan MEA sejak 2015 menyebutkan bahwa integrasi pasar belum sepenuhnya dalam dilaksanakan dan akan dilakukan evaluasi kembali setelah tahun 2020. Hal ini wajar mengingat pada tahun 2015, terjadi krisis global yang mempengaruhi kinerja keuangan dan perekonomian negara-negara berkembang ASEAN. Kondisi krisis sempat membuat sistem keuangan terpuruk utamanya pada industri perbankan yang merupakan merupakan lembaga yang rentan terhadap perubahan kondisi makroekonomi dan keuangan mengingat perannya sebagai penghimpun dan penyalur dana dalam sistem keuangan (Hadad et. al, 2003). Jika ada masalah terutama pada arus pembayaran, likuiditas bank juga akan terganggu. Hal ini dikarenakan perbedaan maturitas aset dan kewajiban pada struktur neraca yang memunculkan mismatches maturity (Allen \& Gale, 2004) dan adanya fasilitas pinjaman antar bank yang berpotensi memunculkan risiko sistemik meski bank lain dalam kondisi solven (Freixas et. al, 2000).

Kinerja keuangan perbankan dapat dilihat dari empat komponen, yakni capital, earning and efficiency, asset quality, serta liquidity. Kinerja keuangan bank yang buruk akibat adanya kondisi krisis maupun adanya kebijakan pemerintah dapat meningkatkan potensi risiko sistemik. Risiko sistemik bisa terjadi secara tiba-tiba akibat gangguan 
sistem pembayaran dan arus kredit, serta jatuhnya nilai aset (Group of Ten, 2001). Terkait dengan penyebab munculnya risiko sistemik, Billio et al. (2011) dan Bisias et. al. (2012) memperkenalkan konsep 4L (leverage, liquidity, loss, dan linkage) yang menjelaskan bahwa jika leverage bank terlalu tinggi karena mengejar return yang tinggi maka probability of loss akan meningkat. Jika bank rugi, akan timbul masalah likuiditas yang berdampak pada jaringan sistem keuangan. Info kerugian bank ini membuat deposan kehilangan kepercayaan dan melakukan bank run (Chen, 1999; Allan \& Gale, 2004; Rose \& Hudgin, 2010).

Penelitian ini penting untuk dilakukan mengingat kontribusinya dalam evaluasi kinerja keuangan perbankan di negara-negara ASEAN dan terkait pengaruh kinerja keuangan terhadap peningkatan risiko sistemik sebelum dan setelah integrasi pasar perdagangan bebas Masyarakat Ekonomi ASEAN (MEA) diterapkan. Lebih lanjut, penelitian ini sangat mendukung dan telah sejalan dengan roadmap penelitian Universitas Islam 45 yang menyebutkan bahwa pada 2018-2026 penelitian akademik lebih berfokus pada penerapan lokalregional model teknologi dan rekayasa sosial yang malahirkan produk berupa kebijakan untuk kemudian dilakukan pengembangan penelitian berstandar internasional.

\section{METODE}

Peneliti melakukan perhitungan atas kualitas aset perbankan yang diproksikan dengan non performing loan, likuiditas perbankan yang diproksikan dengan loan to deposit ratio, modal bank yang diproksikan dengan owner's equity to total asset ratio, serta risiko sistemik menggunakan perhitungan risiko sistemik diakukan dengan menggunakan metode MES yakni pada saat pasar mengalami distress mengikuti penelitian Acharya (2010) dan Idier et.al. (2013). Acharya (2010) mendefinisikan MES bank sebagai perkiraan kerugian yang conditional pada saat default pasar lebih besar dari VaR pada $\alpha \%$ yang dalam hal ini adalah 5\%. MES bank $i$ diestimasi dengan menghitung rata-rata return saham bank pada saat conditional event yakni hari dimana pasar rugi secara ekstrim. Adapun model pengukuran MES menurut Acharya (2010) sebagai berikut:

$\operatorname{MES}_{i}^{5 \%}=-\mathrm{E}\left\{\frac{\mathrm{w}_{1}{ }^{\mathrm{i}}-1}{\overline{\mathrm{W}_{0}{ }^{\mathrm{i}}}} \mathrm{I}_{5 \%}\right\}$

$\frac{\mathrm{W}_{1}{ }^{\mathrm{i}}}{\mathrm{W}_{0}{ }^{\mathrm{i}}}$ : return saham bank

$\mathrm{I}_{5 \%}$ : Hari-hari pada saat pasar dengan 5\% return terburuk.

Perhitungan jumlah hari dalam hal ini adalah sekitar 250 hari, dimana Bartram et. al. (2007) juga menggunakan estimasi sekitar 250 hari untuk mengukur hari-hari terburuk return pasar pada estimasi risiko sistemik. MES bank $i$ kemudian diestimasi dengan menghitung rata-rata return saham bank pada saat conditional event yakni hari dimana pasar rugi secara ekstrim. Adapun model pengukuran MES pada periode waktu $\left[T_{1} ; T_{2}\right]$ menurut Archarya (2010) sebagai berikut:

$M E S_{i}^{5} \%_{[T 1 ; T 2]}=\frac{1}{\# \text { days in }\left[T_{1} ; T_{2}\right]} \Sigma_{t ; \text { system is in its } 5 \% \text { tail }} R_{t}^{i}$

$R_{t}^{i}:$ return saham bank $i$ pada waktu $t$ dengan $t \in\left[T_{1} ; T_{2}\right]$

\section{HASIL}

Secara umum, jika dilihat dari periode sebelum dan setelah integrasi atas MEA terdapat beberapa temuan yang dapat diperoleh dari grafik di bawah ini. Jika dilihat dari grafik terlihat bahwa kualitas aset yang dilihat dari tingkat non performing loan lebih rendah nilainya pada saat sebelum integrasi dibandingkan dengan pada saat setelah terjadi integrasi MEA. Hal yang sama terlihat pada proporsi modal bank dan risiko sistemik yang meningkat setelah terjadinya integrasi MEA. Kondisi sebaliknya, bahwa tingkat likuiditas mengalami penurunan setelah terjadi integrasi MEA. Penurunan likuiditas dapat menjadi indikasi buruk bagi kondisi perbankan. Meski prosentase penurunan dan/atau kenaikan atas kualitas aset, likuiditas, modal, serta risiko sistemik tidak terjadi secara signifikan namun setidaknya kodisi ini menunjukkan adanya perbedaan sebelum dan setelah integrasi dilakukan mengingat periode penelitian yang tidak ditarik dalam waktu lama karena keterbatasan akses data. 
Rinda Siaga P, Evaluasi Kinerja Perbankan ASEAN Terkait Peningkatan Risiko Sistemik dalam Integrasi Pasar Perdagangan Bebas Masyarakat Ekonomi ASEAN (MEA)

\section{Gambar 1}

Prosentase Penurunan dan/atau Kenaikan Atas Kualitas Aset, Likuiditas, Modal dan Risiko

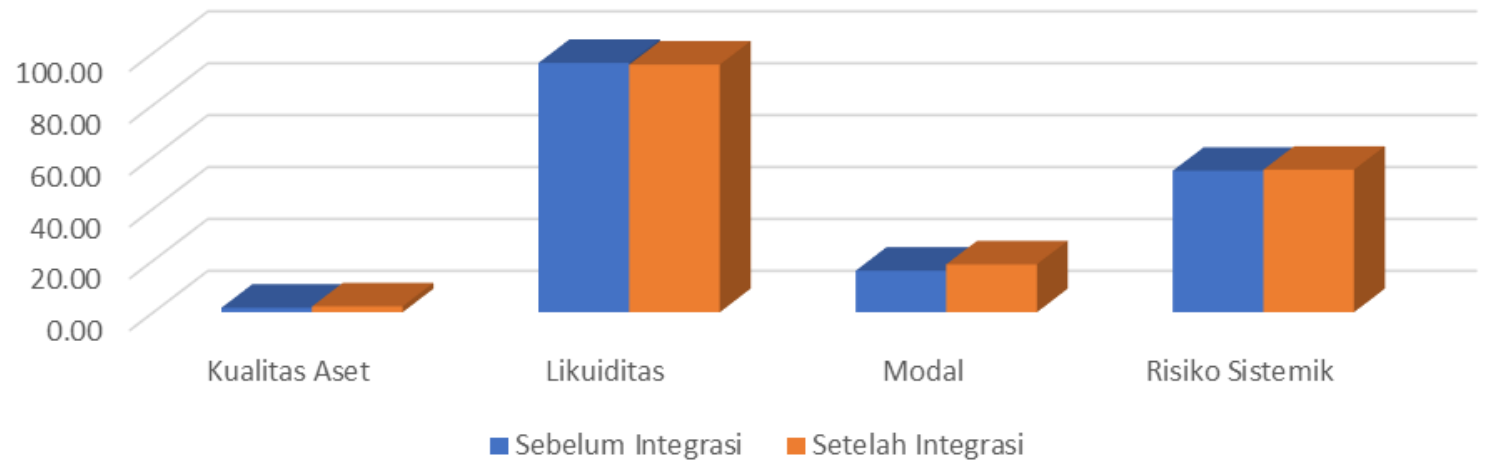

Sumber: Data diolah, 2019.

Penelitian ini menggunakan sampel perbankan di negara-negara berkembang seperti Indonesia dan Malaysia sepanjang tahun 2013 hingga 2018. Penggunaan sampel negara berkembang ini mengingat negara berkembang sangat mudah terpengaruh oleh kondisi krisis. Peneliti sudah berupaya mengumpulkan data laporan keuangan perbankan di negara ASEAN lainnya seperti Thailand, Vietnam dan Filipina namun data tidak lengkap sehingga sampel yang memenuhi hanya Indonesia dan Malaysia. Peneliti melakukan perhitungan atas kualitas aset perbankan yang dimasukkan dalam data variabel independen X1, likuiditas perbankan yang dimasukkan dalam data variabel independen X2, modal bank yang dimasukkan dalam data variabel independen X3, serta risiko sistemik yang dimasukkan dalam data untuk variabel dependen Y. Terdapat 96 total observasi atas regresi linier berganda menggunakan data panel. Berikut adalah hasil pengujian atas pemilihan model (fixed effect, common effect, random effect) yang akan digunakan.

Tabel 1

Pengujian Pemilihan Model

Test cross-section fixed effects

\begin{tabular}{|c|c|c|c|}
\hline Effects Test & Statistic & d.f. & Prob. \\
\hline Cross-section F & 4.740947 & $(15,32)$ & 0.0001 \\
\hline \multicolumn{4}{|c|}{ Test cross-section random effects } \\
\hline Test Summary & Chi-Sq. Statistic & Chi-Sq. d.f. & Prob. \\
\hline Cross-section random & 7.455782 & 3 & 0.0487 \\
\hline
\end{tabular}

Sumber: Data diolah, 2019.

Berdasarkan hasil Uji Chow diketahui bahwa nilai probabilitas kurang dari 0.05 sehingga model fixed effect lebih dipilih dibandingkan dengan common effect. Pengujian kedua dilakukan untuk memilih antara model fixed effect dengan random effect dan hasilnya adalah model fided effect yang dipergunakan mengingat nilai probabilitas kurang dari 0.05. jika nilai probabilitas pada hasil Uji Hausman menunjukkan angka lebih dari 0.05 maka model random effect yang akan dipilih.

Tabel 2

Hasil regresi Panel

\begin{tabular}{lrrrr}
\hline \multicolumn{1}{c}{ Variable } & Coefficient & Std. Error & t-Statistic & Prob. \\
$\mathrm{C}$ & -3.433279 & 0.110633 & -31.03308 & 0.0000 \\
$\mathrm{X} 1$ & 1.901418 & 0.306532 & 6.202998 & 0.0000 \\
\hline $\mathrm{X} 2$ & 0.241739 & 0.067318 & 3.591010 & 0.0011 \\
\hline $\mathrm{X} 3$ & -0.766736 & 0.421472 & & \\
\hline R-squared & 0.681032 & & & \\
\hline Adjusted R-squared & 0.507049 & & & \\
\hline F-statistic & 3.914367 & & & \\
\hline Prob (F-statistic) & 0.000337 & & & \\
\hline Durbin-Watson stat & 3.085319 & & & \\
\hline Sumber: Data diolah 20185 & & \\
\hline
\end{tabular}

Sumber: Data diolah, 2019. 
Berdasarkan hasil regresi panel, diketahui bahwa kualitas aset perbankan dan likuiditas memberikan pegaruh positif signifikan terhadap risiko sistemik. Hal ini dapat dijelaskan bahwa pada saat prosentase nilai non performing loan naik maka risiko sistemik akan mengalami peningkatan. Bank akan mengalami masalah likuiditas saat banyak pinjaman yang tak tertagih karena para peminjam tidak melakukan pembayaran sesuai dengan kesepakatan, sementara pihak bank tetap harus membayar kewajibannya atas bunga yang dijanjikan atas pengumpulan dana pihak ketiga dan/atau pengeluaran atas biaya operasional lain. Hasil penelitian ini sejalan dengan penelitian yang dilakukan Wei $\beta$ et. al. (2015) bahwa peningkatan risiko kredit dapat memegaruhi peningkatan risiko sistemik utamanya pada saat kondisi krisis.

Selain aset perbankan, likuiditas juga memberikan pengaruh yang positif signifikan terhadap peningkatan risiko sistemik. Meski secara teori, perbankan akan mengalami kesulitan likuiditas jika nilai loan to deposit ratio menunjukkan angka yang rendah, namun jika likuiditas perbankan tinggi pun belum tentu menunjukkan bahwa bank mengalami kondisi yang sehat. Jika Bank memiliki tingkat likuiditas yang tinggi ada kemungkinan bahwa bank tidak dapat menyalurkan dana yang diperoleh sesuai dengan fungsinya sebagai penyimpan dan penyalur uang. Jika Bank terlalu banyak menyimpan dana dan tidak menyalurkannya dalam bentuk produk-produk keuangan maupun investasi lainnya, Bank akan cenderung tidak solven dan kondisi ini akan memengaruhi kondisi perekonomian dan/atau sistem keuangan yang dapat meningkatkan risiko sistemik.

Pada hasil regresi juga diketahui modal banyak Bank memengaruhi risiko sistemik secara negatif pada tingkat kepercayaan 90\% (pada penelitian ini menggunakan tingkat kepercayaan 95\%). Tanda negatif menunjukkan bahwa jika modal banyak Bank berkurang maka risiko sistemik akan meningkat dan demikian juga sebaliknya. Temuan ini sejalan dengan teori bahwa Bank dengan permodalan yang kuat akan dapat bertahan. Penelitian sebelumnya jika menemukan bahwa banyak Bank dengan modal yang besar akan dapat memberikan kontribusi yang lebih besar terhadap kejadian sistemik jika banyak Bank tersebut mengalami kondisi default (Yun and Moon, 2014; Jonghe et. al., 2015; Pangestuti, 2018).

\section{SIMPULAN}

Beberapa temuan utama dalam penelitian ini adalah bahwa (a) peningkatan risiko sistemik dipengaruhi oleh peningkatan risiko atas kualitas aset yang dilihat dari peningkatan prosentase non performing loan; (b) likuiditas bank memberikan pengaruh positif signifikan terhadap peningkatan risiko sistemik; (c) bank-bank dengan modal yang besar dapat memberikan pengaruh atas peningkatan risiko sistemik jika menggunakan tingkat kepercayaan $90 \%$. Pemerintah diharapkan dapat melakukan mitigasi terhadap peningkatan potensi risiko sistemik utamanya setelah integrasi perdagangan bebas di ASEAN.

\section{DAFTAR PUSTAKA}

Acharya, Viral, V. (2009). A theory as systemic risk and design of prudential bank regulation. PhD Dissertaion of NYU.

Bartram, S., Brown, G.W., Hund, J. (2007). Estimating Systemic Risk in the International Financial System. Journal of Financial Economics 86, 835-Bekhet, Ali H., Shorouq F. K. Eletter. (2014). Credit risk assessment model for Jordanian commercial banks: Neural Scoring Approach. Review of Development Science.

Billio, M., Getmansky, M., Lo, Andres, dan Pellizon. (2010). Measuring systemic risk in the finance and insurance sector. MIT Sloan School, working paper \#4774-10.

Bisias et al. (2012). A survey of systemic risk analytics. Offfice of Financial Research, Working Paper \#0001.

Freixas, X., Parigi, B. M., dan Rochet, J. C. (2000). Systemic risk, interbank relations, and liquidity proviosion by the central bank. Journal of Money, Credit and Banking, 32, 611-638.

Chen, Yehning. (1999). Banking panics: The rule of the first-come, first-served rule and information externalities. Journal of Political Economy, 107, No.5.

Group of Ten. (2001). Consolidation in the financial sector. Working Group Report, January.

Hadad, Muliaman, Santoso, Wimboh, dan A., Bambang. (2003). Indikator awal krisis perbankan. www.bi.go.id diakses pada 12 Oktober 2015.

Idier, Julien, et. al. (2013). How useful is the Marginal Expected Shortfall for the measurement of systemic exposure? A practical assessment. Euro System, Working Paper Series, No. 1546.

Inpres No. 6 Tahun 2014 Tentang Peningkatan daya Saing Nasional Dalam Rangka Menghadapi MEA

Jonghe, O.D., Diepstraten, M., Schepens, G. (2015). Bank's size, scope, and systemic risk: What the role for conflicts of interest. Journal of Banking and Finance.

Pangestuti, R.S. (2018). Pengaruh Risiko Sistemik terhadap Risiko Kredit dan Risiko Likuiditas pada Perbankan di ASEAN-4. Jurnal Ilmiah Akuntansi fakultas Ekonomi, Vol.4, No.1.

Rose dan Hudgin, S. (2010). Bank and other financial institution. Mc Graw Hill. 
Rinda Siaga P, Evaluasi Kinerja Perbankan ASEAN Terkait Peningkatan Risiko Sistemik dalam Integrasi Pasar Perdagangan Bebas Masyarakat Ekonomi ASEAN (MEA)

Weiß, G.N.F., Bostandzic, D., Neumann, S. (2014). What factors drive systemic risk during international crises? Journal of Banking and Finance, 41, 78-96.

Yun, J., Moon, H. (2014). Measuring systemic risk in the Korean banking sector via dynamic conditional correlation models. Pasific-Basin Finance Journal, 27, 94-114. 